\title{
The calculation of quality indicators for long term care facilities in 8 countries (SHELTER project)
}

\author{
Dinnus HM Frijters ${ }^{1 *}$, Henriëtte G van der Roest ${ }^{1}$, lain Gl Carpenter ${ }^{2}$, Harriet Finne-Soveri ${ }^{3}$, Jean-Claude Henrard ${ }^{4}$, \\ Angela Chetrit ${ }^{5}$ Jacob Gindin ${ }^{5}$ and Roberto Bernabei ${ }^{6}$
}

\begin{abstract}
Background: Performance indicators in the long term care sector are important to evaluate the efficiency and quality of care delivery. We are, however, still far from being able to refer to a common set of indicators at the European level.

We therefore demonstrate the calculation of Long Term Care Facility Quality Indicators (LTCFQIs) from data of the European Services and 트ealth for Elderly in Long TERm Care (SHELTER) project. We explain how risk factors are taken into account and show how LTC facilities at facility and country level can be compared on quality of care using thresholds and a Quality Indicator sum measure.

Methods: The indicators of Long Term Care Facility quality of care are calculated based on methods that have been developed in the US. The values of these Quality Indicators (QIs) are risk adjusted on the basis of covariates resulting from logistic regression analysis on each of the Qls. To enhance the comparison of Qls between facilities and countries we have used the method of percentile thresholds and developed a QI sum measure based on percentile outcomes.
\end{abstract}

Results: In SHELTER data have been collected with the interRAI Long Term Care Facility instrument (interRAI-LTCF). The data came from LTC facilities in 7 European countries and Israel. The unadjusted values of the LTCF Quality Indicators differ considerably between facilities in the 8 countries. After risk adjustment the differences are less, but still considerable. Our QI sum measure facilitates the overall comparison of quality of care between facilities and countries.

Conclusions: With quality indicators based on assessments with the interRAI LTCF instrument quality of care between LTC facilities in and across nations can be adequately compared.

Keywords: Quality indicators, Long term care facility, SHELTER project

\section{Background}

Quality of care is a complex, multi-dimensional concept. The US Institute of Medicine defines quality of care as "the degree to which health services for individuals and populations increase the likelihood of desired health outcomes which are consistent with current professional knowledge" (www.iom.edu). There is interest in the creation of performance indicators that can measure quality by examining the structure, process, and outcomes of care. One method of identifying potentially good and poor professional quality of care is the use of quality

\footnotetext{
*Correspondence: d.frijters@vumc.nl

${ }^{1}$ EMGO Institute for Health and Care Research, VU University Medical Center, Amsterdam, the Netherlands

Full list of author information is available at the end of the article
}

indicators, which can be defined as "markers that indicate either the presence or absence of potentially poor care practices or outcomes". The aim of quality indicators use is therefore to identify the clinical areas that can benefit from improvement of the care process and to define performance of individual care providers [1].

Quality Indicators (QIs) for monitoring quality of care in nursing homes have been developed using assessment data from the widely implemented Resident Assessment Instrument (RAI) for Long Term Care [2-4]. Routine monitoring of these QIs led to QI reports being used for best practice comparison between nursing homes. A study commissioned by the US Centers for Medicare and Medicaid Services (CMS) demonstrated that the items from routine use of the RAI for Long Term Care

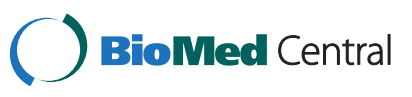


in US Nursing Homes are reliable and that they can be used for the stimulation of improvement of care and reporting to the general public [5,6]. For most of the QIs some risk adjustment is necessary to allow useful comparison of them between facilities [7,8]. Although the relationship between outcomes and good and bad care practices were not equally strong for all available QIs, 10 QIs had a good enough relationship between identifiable pro-active and responsive care practices. These QIs have been selected by CMS for periodically public reporting at facility level.

A four step approach was used in the CMS commissioned development and validation of QI's for nursing homes.

1. Selecting indicators of professional quality of care. Using large datasets gathered from routine practice, focus groups discussed which assessment items or combination of items might indicate dimensions of quality of care (face validity). QIs then were defined together with the method for calculating numerator and denominator values (construct validity). To be useful the indicators must, in addition, show enough variance between facilities, have high enough prevalence, and show sensitivity to change when care practices change;

2. Correlating indicators with quality of care. Experts must agree that high scores (or low scores) on the indicators in a facility or agency correspond to bad (or good) quality of care. This was formalized by research that identified care practices that correlated well with indicator scores pro-actively (i.e. prevent problems) or responsively (i.e. remedy problems);

3. Identifying person level risk factors. Factors that legitimately increased or reduced the likelihood of an individual scoring on the indicators were identified by regression analysis of client characteristics as recorded in the assessment items.

4. Identifying service level bias. Service level bias (ascertainment bias) manifests itself in two related forms: service/facility admission practice, and staff competence in observation and recording. Nursing homes that admit a relatively large number of clients with some specific indicator problems often continued to score high on these indicators at follow-up, despite risk adjustment. When experts examined the practice of these services/ facilities, the quality of care in these indicators areas was not necessarily poor. A Facility Admission Profile (FAP) covariate was defined to resolve this matter [5].

In two papers that came out of the European AgeD in HOme Care (ADHOC) study [9], the calculation of QIs for Home Care was explained and discussed $[10,11]$.
In this paper, similarly, we aim to explain and discuss Quality Indicators for Long Term Care Facilities (LTCFQIs) based on interRAI LTCF assessments [12] and their calculation. To do that we specifically show results of the calculation at country level in the 8 countries participating in the European Services and Health for Elderly in Long TERm care (SHELTER) study [13].

\section{The list of long term care facility quality indicators}

The LTCFQIs shown in this paper were initially commissioned on contract by CMS [5]. The indicators were developed for use with the mandated MDS 2.0 assessments for Nursing Homes. We have 'translated' them to be used with the interRAI LTCF instrument [12]. Most could directly be calculated by substituting the MDS 2.0 items with corresponding LTCF items. On occasion some codes in the LTCF items needed to be collapsed to give the same code set as in MDS 2.0. For some of the indicators the conversion of items could not be done or was too complex. The indicators 'depressed/anxious mood worsening' and 'walking performance maintenance/ improvement' were for that reason deleted from the list.

The results of the calculation of the LTCFQI's have been quarterly reported in the last 6 years to facilities in the Netherlands that used the interRAI LTCF which appears to have had a positive effect on the quality of care in these facilities [14]. On request of these facilities three QI's were added to the list: 'Anti-depressant use prevalence, 'Influenza vaccination prevalence' and 'Depression prevalence' These QIs were borrowed from the Home Care Quality Indicators set [15] and are included in this study.

Table 1 gives the list of the LTCFQI's, their name, numerator, denominator exclusions, and risk adjusters.

QI scores are derived from the individual item scores of the interRAI LTCF assessment as indicated in Table 1. They are calculated for the individual person (yes/no/not applicable) and summed per facility or any higher level of aggregation as a numerator/denominator ratio or percentage.

The CMS commissioned study identified risk factors, not necessarily under the control of the facility, that affect the prevalence of some quality indicators [5]. These risk factors are at the level of the individual resident and include differences in various characteristics of the resident, occasionally expressed as a scale value:

- activities of daily living (ADL) ability, measured by the ADL-long form scale - (ADL-lf) [16].

- cognitive function, measured by the Cognitive Performance Scale (CPS) [17].

- depressed mood, measured by the Depression Rate Scale (DRS) [18].

The QI's are case-mixed corrected by logistical regression analysis, with presence or absence of the QI 
Table 1 Quality indicators for the interRAI LTCF instrument

\begin{tabular}{|c|c|c|c|c|c|}
\hline$\#^{1}$ & Indicator & Numerator $^{2}$ & Denominator exclusions $^{3}$ & Risk adjustment & FAP $^{4}$ \\
\hline \multicolumn{6}{|c|}{ Prevalence indicators } \\
\hline \multicolumn{6}{|c|}{ Mental functions } \\
\hline beh01 & $\begin{array}{l}\text { Behaviour problem } \\
\text { prevalence }\end{array}$ & Behaviour symptoms & Comatose. & & + \\
\hline \multirow[t]{2}{*}{ beh02 } & \multirow{2}{*}{$\begin{array}{l}\text { High risk behaviour problem } \\
\text { prevalence }\end{array}$} & \multirow{2}{*}{ Behaviour symptoms } & Comatose. & & \multirow[t]{2}{*}{+} \\
\hline & & & Low risk behaviour (see beh03) & & \\
\hline \multirow[t]{2}{*}{ beh03 } & \multirow{2}{*}{$\begin{array}{l}\text { Low risk behaviour problem } \\
\text { prevalence }\end{array}$} & \multirow[t]{2}{*}{ Behaviour symptoms } & Comatose. & & \multirow[t]{2}{*}{+} \\
\hline & & & $\begin{array}{l}\text { Dependent in daily decision } \\
\text { making or short term memory } \\
\text { problem. Schizophrenic or } \\
\text { bipolar depression. }\end{array}$ & & \\
\hline dep01 & Depression prevalence & Depression Ration Scale score $>=3$ & & & \\
\hline \multicolumn{6}{|c|}{ Health problems } \\
\hline cnt01 & $\begin{array}{l}\text { Bladder/bowel incontinence } \\
\text { prevalence }\end{array}$ & $\begin{array}{l}\text { Frequent or always bladder or bowel } \\
\text { incontinent }\end{array}$ & $\begin{array}{l}\text { Comatose, end-stage disease or } \\
\text { hospice care. }\end{array}$ & & + \\
\hline \multirow[t]{2}{*}{ cnt05 } & \multirow[t]{2}{*}{$\begin{array}{l}\text { High risk bladder/bowel } \\
\text { incontinence prevalence }\end{array}$} & \multirow[t]{2}{*}{$\begin{array}{l}\text { Frequent or always bladder or bowel } \\
\text { incontinent }\end{array}$} & $\begin{array}{l}\text { Comatose, end-stage disease or } \\
\text { hospice care. }\end{array}$ & & \multirow[t]{2}{*}{+} \\
\hline & & & Low risk incontinence (see cnt06) & & \\
\hline \multirow[t]{3}{*}{ cnt06 } & \multirow[t]{3}{*}{$\begin{array}{l}\text { Low risk bladder/bowel } \\
\text { incontinence prevalence }\end{array}$} & \multirow[t]{3}{*}{$\begin{array}{l}\text { Frequent or always bladder or bowel } \\
\text { incontinent }\end{array}$} & $\begin{array}{l}\text { Comatose, end-stage disease or } \\
\text { hospice care. }\end{array}$ & & \multirow[t]{3}{*}{+} \\
\hline & & & $\begin{array}{l}\text { Severely impaired decision } \\
\text { making and short term } \\
\text { memory problem. }\end{array}$ & & \\
\hline & & & $\begin{array}{l}\text { Total ADL dependence in bed } \\
\text { mobility, transfer toilet or locomotion. }\end{array}$ & & \\
\hline cnt04 & Urinary tract infection & UTI & $\begin{array}{l}\text { End-stage disease or } \\
\text { hospice care. }\end{array}$ & & \\
\hline inf01 & Infections prevalence & $\begin{array}{l}\text { Pneumonia, COPD, septicemia, } \\
\text { Sexually transmitted disease, UTI or } \\
\text { viral hepatitis }\end{array}$ & $\begin{array}{l}\text { End-stage disease or } \\
\text { hospice care. }\end{array}$ & & + \\
\hline nut01 & Feeding tube prevalence & & $\begin{array}{l}\text { Comatose, end-stage disease } \\
\text { or hospice care. }\end{array}$ & $\begin{array}{l}\text { (1) Swallowing problem } \\
\text { and stroke }\end{array}$ & + \\
\hline bmi0x & $\begin{array}{l}\text { Low body mass index } \\
\text { prevalence }\end{array}$ & $\mathrm{bmi}<=19$ & $\begin{array}{l}\text { End-stage disease or } \\
\text { hospice care. }\end{array}$ & & + \\
\hline pai01 & $\begin{array}{l}\text { Inadequate pain } \\
\text { management prevalence }\end{array}$ & Daily moderate or worse pain & & $\begin{array}{l}\text { (1) Dependent in daily } \\
\text { decision making }\end{array}$ & + \\
\hline pru01 & Pressure ulcer prevalence & PU & & & + \\
\hline \multirow[t]{2}{*}{ pru02 } & \multirow{2}{*}{$\begin{array}{l}\text { High risk pressure ulcer } \\
\text { prevalence }\end{array}$} & \multirow[t]{2}{*}{ PU } & Comatose. & & \multirow[t]{2}{*}{+} \\
\hline & & & Low risk PU (see pru03) & & \\
\hline \multirow[t]{2}{*}{ pru03 } & \multirow{2}{*}{$\begin{array}{l}\text { Low risk pressure ulcer } \\
\text { prevalence }\end{array}$} & \multirow[t]{2}{*}{ PU } & Comatose. & & \multirow[t]{2}{*}{+} \\
\hline & & & $\begin{array}{l}\text { Extensive assistance or more } \\
\text { with toilet transfer or bed } \\
\text { mobility. }\end{array}$ & & \\
\hline bur0x & $\begin{array}{l}\text { Burns, skin tears or cuts } \\
\text { prevalence }\end{array}$ & Burns, skin tears or cuts & & & + \\
\hline \multicolumn{6}{|c|}{ Treatments and procedures } \\
\hline soc02 & Little/no activity prevalence & Little or no time involved in activities & $\begin{array}{l}\text { Comatose, end-stage disease or } \\
\text { hospice care. }\end{array}$ & & \\
\hline \multirow[t]{2}{*}{ drg01 } & Antipsychotic prevalence & Use of antipsychotic(s) & $\begin{array}{l}\text { End-stage disease or } \\
\text { hospice care. }\end{array}$ & & + \\
\hline & & & Psychotic disorder. & & \\
\hline \multirow[t]{2}{*}{ drg02 } & $\begin{array}{l}\text { High risk antipsychotic } \\
\text { prevalence }\end{array}$ & Use of antipsychotic(s) & $\begin{array}{l}\text { End-stage disease or } \\
\text { hospice care. }\end{array}$ & & + \\
\hline & & & Low risk AP (see drg03) & & \\
\hline
\end{tabular}


Table 1 Quality indicators for the interRAI LTCF instrument (Continued)

\begin{tabular}{|c|c|c|c|c|c|}
\hline \multirow[t]{5}{*}{$\operatorname{drg} 03$} & \multirow[t]{5}{*}{$\begin{array}{l}\text { Low risk antipsychotic } \\
\text { prevalence }\end{array}$} & \multirow[t]{5}{*}{ Use of antipsychotic(s) } & $\begin{array}{l}\text { End-stage disease or } \\
\text { hospice care. }\end{array}$ & & \multirow[t]{5}{*}{+} \\
\hline & & & Psychotic disorder. & & \\
\hline & & & $\begin{array}{l}\text { Dependent in daily decision } \\
\text { making. }\end{array}$ & & \\
\hline & & & Short term memory problem. & & \\
\hline & & & Behaviour symptoms score. & & \\
\hline adp01 & Antidepressant prevalence & Use of antidepressant(s) & & & + \\
\hline vac01 & $\begin{array}{l}\text { Influenza vaccination } \\
\text { prevalence }\end{array}$ & $\begin{array}{l}\text { Influenza vaccination in last } \\
12 \text { months }\end{array}$ & & & \\
\hline \multirow[t]{2}{*}{ cat02 } & \multirow[t]{2}{*}{$\begin{array}{l}\text { Indwelling catheter } \\
\text { prevalence }\end{array}$} & \multirow[t]{2}{*}{ Indwelling catheter } & \multirow[t]{2}{*}{$\begin{array}{l}\text { End-stage disease or } \\
\text { hospice care. }\end{array}$} & $\begin{array}{l}\text { (1) Frequent or always } \\
\text { bowel incontinent }\end{array}$ & \\
\hline & & & & (2) Stage 3+PU & \\
\hline res01 & $\begin{array}{l}\text { Physical restraints use } \\
\text { prevalence }\end{array}$ & $\begin{array}{l}\text { Daily used trunk restraint or chair } \\
\text { that prevents rising }\end{array}$ & & & \\
\hline \multicolumn{6}{|c|}{ Incidence indicators } \\
\hline \multicolumn{6}{|c|}{ Physical functions } \\
\hline \multirow[t]{2}{*}{ adl01 } & \multirow[t]{2}{*}{ Late-loss ADL decline } & \multirow{2}{*}{$\begin{array}{l}\text { Scores as compared to previous } \\
\text { scores }{ }^{6} \text { for bed mobility, transfer } \\
\text { toilet, eating, toilet use: }+1 \text { on at } \\
\text { least two of the items or }+2 \text { on } \\
\text { one item. }\end{array}$} & $\begin{array}{l}\text { Comatose, end-stage disease } \\
\text { or hospice care. }\end{array}$ & & \\
\hline & & & $\begin{array}{l}\text { At previous assessment such a } \\
\text { (high/low) score on items that } \\
\text { numerator conditions cannot } \\
\text { be met. }\end{array}$ & & \\
\hline adl02 & $\begin{array}{l}\text { ADL decline following } \\
\text { an improvement }\end{array}$ & $\begin{array}{l}\text { Score on adl-If }{ }^{8} \text { lower than previous } \\
\text { AND score on previous adl-If higher } \\
\text { than at the assessment before } \\
\text { previous. }\end{array}$ & $\begin{array}{l}\text { Comatose, end-stage disease } \\
\text { or hospice care. }\end{array}$ & & \\
\hline \multirow[t]{2}{*}{ adl03 } & \multirow[t]{2}{*}{ ADL improvement } & \multirow[t]{2}{*}{ Score on adl-If lower than previous } & $\begin{array}{l}\text { Comatose, end-stage disease } \\
\text { or hospice care. }\end{array}$ & & \\
\hline & & & $\begin{array}{l}\text { Person or caregivers do not } \\
\text { believe improvement possible. }\end{array}$ & & \\
\hline \multirow[t]{3}{*}{ mob01 } & \multirow[t]{3}{*}{ Locomotion worsening } & \multirow{3}{*}{$\begin{array}{l}\text { Score on locomotion adl higher } \\
\text { than previous }\end{array}$} & \multirow{3}{*}{$\begin{array}{l}\text { Comatose, end-stage disease } \\
\text { or hospice care. }\end{array}$} & (1) Fell & + \\
\hline & & & & $\begin{array}{l}\text { (2) Extensive assistance } \\
\text { eating }\end{array}$ & \\
\hline & & & & $\begin{array}{l}\text { (3) Extensive assistance } \\
\text { toilet use }\end{array}$ & \\
\hline \multirow[t]{3}{*}{ fal01 } & \multirow[t]{3}{*}{ Falls increase } & \multirow[t]{3}{*}{ Fell in last 30 days } & \multirow{3}{*}{$\begin{array}{l}\text { At previous assessment not a } \\
\text { fall in last } 30 \text { days }\end{array}$} & (1) Bedbound & \\
\hline & & & & (2) Wandering behaviour & \\
\hline & & & & $\begin{array}{l}\text { (3) Unsteady gait and } \\
\text { cps }>=2\end{array}$ & \\
\hline \multicolumn{6}{|c|}{ Mental functions } \\
\hline \multirow[t]{4}{*}{$\operatorname{cog} 01$} & \multirow[t]{4}{*}{ Cognitive decline } & \multirow[t]{4}{*}{ Score on cps higher than previous } & \multirow[t]{4}{*}{$\begin{array}{l}\text { Comatose, end-stage disease or } \\
\text { hospice care. }\end{array}$} & $\begin{array}{l}\text { (1) Frequent or always } \\
\text { bowel incontinent }\end{array}$ & + \\
\hline & & & & (2) Fell in last 30 days & \\
\hline & & & & (3) Weight loss & \\
\hline & & & & (4) $76+$ years old & \\
\hline \multirow[t]{2}{*}{ com01 } & Communication decline & $\begin{array}{l}\text { Score on making self understood }+ \\
\text { ability to understand others higher }\end{array}$ & $\begin{array}{l}\text { Comatose, end-stage disease } \\
\text { or hospice care. }\end{array}$ & $\begin{array}{l}\text { (1) Extensive assistance } \\
\text { eating }\end{array}$ & + \\
\hline & & than previous & & (2) Short term memory & \\
\hline del01 & Delirium new or persistent & $\begin{array}{l}\text { Score of } 2 \text { on one or more of the } \\
\text { delirium items OR a previous score } \\
\text { of } 2 \text { and now } 1 \text { OR now score of } 1 \\
\text { and cps }<4\end{array}$ & $\begin{array}{l}\text { Comatose, end-stage disease } \\
\text { or hospice care. }\end{array}$ & & + \\
\hline beh04 & Behaviour problem decline & $\begin{array}{l}\text { Sum of behaviour symptoms scores } \\
\text { higher than previous }\end{array}$ & Comatose & (1) Not aphasia & + \\
\hline
\end{tabular}


Table 1 Quality indicators for the interRAI LTCF instrument (Continued)

\begin{tabular}{|c|c|c|c|c|c|}
\hline & & & $\begin{array}{l}\text { Previous score of } 0 \text { on all of } \\
\text { the behaviour symptoms }\end{array}$ & $\begin{array}{l}\text { (2) Moderate or severe } \\
\text { decision making problem }\end{array}$ & \\
\hline \multicolumn{6}{|c|}{ Health problems } \\
\hline \multirow[t]{3}{*}{ cnt02 } & \multirow[t]{3}{*}{ Bowel continence decline } & \multirow{3}{*}{$\begin{array}{l}\text { Score on bowel incontinence higher } \\
\text { than previous }\end{array}$} & \multirow{3}{*}{$\begin{array}{l}\text { Comatose, end-stage disease } \\
\text { or hospice care. }\end{array}$} & (1) Short term memory & \\
\hline & & & & $\begin{array}{l}\text { (2) Extensive assistance } \\
\text { dressing }\end{array}$ & \\
\hline & & & & $\begin{array}{l}\text { (3) Frequent or always } \\
\text { bladder incontinent }\end{array}$ & \\
\hline \multirow[t]{4}{*}{ cnt03 } & \multirow[t]{4}{*}{ Bladder continence decline } & \multirow{4}{*}{$\begin{array}{l}\text { Score on bladder incontinence higher } \\
\text { than previous }\end{array}$} & \multirow{4}{*}{$\begin{array}{l}\text { Comatose, end-stage disease } \\
\text { or hospice care. }\end{array}$} & (1) Short term memory & + \\
\hline & & & & $\begin{array}{l}\text { (2) Extensive assistance } \\
\text { dressing }\end{array}$ & \\
\hline & & & & $\begin{array}{l}\text { (3) Severely impaired } \\
\text { decision making }\end{array}$ & \\
\hline & & & & (4) Weight loss & \\
\hline \multirow[t]{3}{*}{ wgt01 } & \multirow[t]{3}{*}{ Weight loss } & \multirow{3}{*}{$\begin{array}{l}5 \% \text { or more weight loss in last } \\
30 \text { days or } 10 \% \text { or more in last } \\
180 \text { days }\end{array}$} & $\begin{array}{l}\text { End-stage disease or } \\
\text { hospice care. }\end{array}$ & (1) Long term memory & + \\
\hline & & & $\begin{array}{l}\text { Participant in weight } \\
\text { loss program. }\end{array}$ & $\begin{array}{l}\text { (2) Extensive assistance } \\
\text { bed mobility }\end{array}$ & \\
\hline & & & & $\begin{array}{l}\text { (3) Daily or almost daily } \\
\text { physically aggressive }\end{array}$ & \\
\hline pan01 & Pain worsening & $\begin{array}{l}\text { Score on pain frequency higher } \\
\text { than previous }\end{array}$ & & $\begin{array}{l}\text { (1) Dependent in daily } \\
\text { decision making }\end{array}$ & + \\
\hline \multirow[t]{4}{*}{ pru04 } & \multirow[t]{4}{*}{ Pressure ulcers worsening } & \multirow[t]{4}{*}{$\begin{array}{l}\text { Score on PU stage higher than } \\
\text { previous }\end{array}$} & & $\begin{array}{l}\text { (1) Extensive assistance } \\
\text { with toilet transfer }\end{array}$ & + \\
\hline & & & & $\begin{array}{l}\text { (2) Fluctuating, precarious, } \\
\text { deteriorating condition }\end{array}$ & \\
\hline & & & & $\begin{array}{l}\text { (3) Extensive assistance } \\
\text { with bed mobility }\end{array}$ & \\
\hline & & & & $\begin{array}{l}\text { (4) Extensive assistance } \\
\text { with locomotion }\end{array}$ & \\
\hline \multicolumn{6}{|c|}{ Treatments and procedures } \\
\hline \multirow[t]{2}{*}{ cat01 } & \multirow[t]{2}{*}{ New indwelling catheter } & \multirow[t]{2}{*}{$\begin{array}{l}\text { Score on indwelling catheter higher } \\
\text { than previous }\end{array}$} & \multirow[t]{2}{*}{$\begin{array}{l}\text { End-stage disease or } \\
\text { hospice care. }\end{array}$} & $\begin{array}{l}\text { (1) Frequent or always } \\
\text { bowel incontinent }\end{array}$ & \\
\hline & & & & $\begin{array}{l}\text { (2) Stage 3+ Pressure } \\
\text { Ulcer }\end{array}$ & \\
\hline
\end{tabular}

${ }^{1}$ Mnemonics for the quality indicators from megaQI project [5].

${ }^{2}$ The ADL's with a $0-6$ range in the interRAI LTCF have first been recoded into a $0-4$ range as in RAI/MDS 2.0 .

${ }^{3}$ Condition at target assessment unless stated differently.

${ }^{4} \mathrm{FAP}=$ Facility Admission Profile. FAP-adjustment means correction on the basis of score of the numerator items at admission, if admission occurred in last five quarters.

${ }_{6}^{5}$ All prevalence indicators are calculated at only one, the last, assessment where the person had stayed 30+ days in the facility.

${ }^{6}$ When an assessment is compared with a previous assessment 6 assessments can be considered, i.e. the target assessment as compared to the previous one; the previous one as compared to the one before that, and so on. It means that in theory a person can be counted 5 times in the calculation of a QI.

7 This condition or a similar condition applies to all of the indicators.

${ }^{8}$ The following scales are used: adl-long form [16], cognitive performance scale [17] and depression rating scale [18].

as the dependent variable and the risk factors as the independent variables. The Facility Admission Profile (FAP) variables are a special kind of risk adjusters in which the values of the QI nominator items at admission are used for risk adjustment.

\section{Methods}

\section{Design}

The SHELTER study has a longitudinal design. Data of residents were collected at baseline, at 6 and at 12 months follow-up.

\section{Population}

The SHELTER data sample consists of Long Term Care Facility residents from 7 European countries, plus Israel [9]. In total 59 private and public LTCFs participated in the study. The number of participating facilities varied widely across the participating countries: 10 in the Czech Republic, 4 in Finland, 6 in France, 9 in Germany, 10 in Italy, 7 in Israel, 4 in the Netherlands, and 9 in England. The aim was to recruit on average 500 residents per country. At baseline data were collected from 4156 residents, at 6 months follow-up data 
from 3761 residents, and at 12 months follow-up from 2686 residents.

The 24 prevalence indicators, (see Table 1), were to be calculated from the last available assessment of a resident which had been in the facility at that time for $30+$ days. The 15 incidence indicators (see Table 1) were to be calculated from the difference between an assessment and the previous assessment of that resident if available.

\section{Data collection}

Assessments were conducted by trained nurses, most of whom worked at the facilities included in the SHELTER study. All were trained in the use of the interRAI-LTCF by experienced trainers in a standardised two day training programme. All trainees received a interRAI-LTCF manual, had access to a Clinical Assessment Protocol manual, and additional training material. On the first day of training the trainees were given an explanation on the interRAI-LTCF and completed a case example from their case load. In the days after they completed an assessment on one or two actual care residents in their facility. On the second day of training those assessments were extensively discussed.

\section{Analysis}

We calculated the LTCFQIs (yes/no/not applicable) for all individuals in the SHELTER dataset [13]. We then entered the risk factors (dependent variable) derived from the CMS study [5] in a stepwise logistic regression analysis for each of the QIs (independent variable) and calculated the Odds Ratios for the risk factors in the SHELTER sample. Since assessment data from the SHELTER study were not necessarily from an initial assessment at admission of the individual to a long term care facility we had no explicit intake data for most of the SHELTER residents. For most residents therefore Facility Admission Profile values were not available.

We compared the unadjusted and risk adjusted individual LTCFQI values by country. Zimmerman showed that for most QIs aggregated facility scores below the 10th percentile scores (indicating 'better' care) and above 75th and 90th (indicating 'worse' care) are useful for indicating potentially excellent and sub-standard quality of care facilities [3].

We then constructed an aggregate QI measure for each country by assigning a score of 1 to every 75 th percentile score or above and an extra 1 to every 90th percentile score or above. We used this aggregate score to compare the overall level of deficiency in quality of care of the 59 facilities and the 8 countries in SHELTER. A country or facility will only be compared with other countries or facilities on a LTCFQI, if the actual number of cases with a positive score on the QI or the predicted number of cases with a positive score is 5 or more. A ranking of the countries or facilities is possible by dividing the aggregate QI measure by the number of LTCQIs for which a score was calculated.

Analyses were conducted using SPSS and Microsoft Excel, see Appendix.

Research ethics approval for the SHELTER study was received for all participating countries and specifically from the following ethics committees: METC VUmc Amsterdam, METC Universita Universita Cattolica del Sacro Cuore Rome, METC National Committee, THL Helsinki, METC Hospital Saint Périne Paris, METC Haifa University, Kaplan Medical Center, The Schools Research Committee Ethical Panel, University of Kent Canterbury, METC University of Ulm, Multi-centric Ethics Committee, General Faculty Hospital Prague. Residents were invited to take part in the study and were free to decline participation. Consent was obtained with assurance of data confidentiality.

\section{Results}

The adjusted LTCFQIs by country are shown in Table 2. For each LTCFQI, the best care (lowest LTCFQI score) country is shown light (green) and the worst care (highest LTCFQI score) country is shown dark (red). There is wide variation in the results of some of the LTCFQIs. For example, the LTCFQI "High Risk Behaviour problem prevalence" shows a range from 22\% (France) to 61\% (England) and the LTCFQI "Physical restraint use prevalence" a range from 1\% (England) to 32\% (Israel).

Additional file 1: Table S1 shows the aggregate LTCFQI measure for each country. The Czech Republic and Israel have by far the lowest summary scores of 5 and 6 ('best' quality of care), England the highest score of 33 ('worst' quality of care). The aggregate scores of the other countries are in between.

The LTCFQI scores of the 59 facilities can be calculated and presented in the same way. The outcomes for facilities, even in one country, show large differences. For example, the four facilities in Finland that participated in the SHELTER study produced the following results:

- Facility 1: 34 QIs calculated; 7 above the 90th percentile, 8 between the 75th and 90th; ranked 50 out of 59 .

- Facility 2: 16 calculated; 2 above the 90th percentile, 1 between the 75th and 90th; ranked 27.

- Facility 3: 36 calculated; 3 and 5; ranked 26.

- Facility 4: 20 calculated; 0 and 1; ranked 2.

\section{Discussion}

In this paper we have explained and discussed the methods for calculating Long Term Care Facility Quality Indicators (LTCFQIs). We used the method to calculate the values of 39 such indicators on assessments from 59 
Table 2 Adjusted long term care quality indicator scores of LTC facilities in 7 European countries and Israel participating in the SHELTER study

\begin{tabular}{|c|c|c|c|c|c|c|c|c|}
\hline & Czech Republic & Finland & France & Germany & Israel & Italy & Netherlands & England \\
\hline Behaviour problem prevalence (beh01) & $0,37^{*}$ & 0,35 & 0,21 & 0,34 & 0,35 & 0,46 & 0,46 & 0,63 \\
\hline High risk behaviour problem prevalence (beh02) & 0,36 & 0,39 & 0,22 & 0,34 & 0,38 & 0,48 & 0,49 & 0,61 \\
\hline Low risk behaviour problem prevalence (beh03) & 0,11 & 0,10 & 0,05 & 0,07 & 0,14 & 0,16 & 0,11 & 0,30 \\
\hline Depression prevalence (dep01) & 0,24 & 0,39 & 0,33 & 0,24 & 0,28 & 0,36 & 0,45 & 0,30 \\
\hline Bladder/bowel incontinence prevalence (cnt01) & 0,72 & 0,91 & 0,72 & 0,75 & 0,73 & 0,63 & 0,76 & 0,81 \\
\hline High risk bladder/bowel incontinence prevalence (cnt05) & 0,97 & 0,99 & 0,97 & 0,96 & 0,97 & 0,96 & 0,96 & 0,96 \\
\hline Low risk bladder/bowel incontinence prevalence (cnt06) & 0,14 & 0,46 & 0,08 & 0,21 & 0,08 & 0,08 & 0,26 & 0,15 \\
\hline Urinary tract Infection (cnt04) & 0,03 & 0,01 & 0,04 & 0,02 & 0,03 & 0,00 & 0,03 & 0,01 \\
\hline Infections prevalence (inf01) & 0,07 & 0,25 & 0,06 & 0,19 & 0,12 & 0,06 & 0,11 & 0,12 \\
\hline Feeding tube prevalence (nut01) & 0,01 & 0,00 & 0,00 & 0,03 & 0,05 & 0,02 & 0,02 & 0,01 \\
\hline Low body mass index prevalence (bmi0x ) & 0,11 & 0,16 & 0,02 & 0,05 & 0,13 & 0,30 & 0,11 & 0,30 \\
\hline Inadequate pain management prevalence (pai01) & 0,13 & 0,10 & 0,05 & 0,13 & 0,04 & 0,04 & 0,14 & 0,16 \\
\hline Pressure ulcer prevalence (pru01) & 0,11 & 0,06 & 0,13 & 0,10 & 0,06 & 0,13 & 0,11 & 0,08 \\
\hline High risk pressure ulcer prevalence (pru02) & 0,17 & 0,07 & 0,18 & 0,16 & 0,08 & 0,17 & 0,18 & 0,10 \\
\hline Low risk pressure ulcer prevalence (pru03) & 0,03 & 0,02 & 0,03 & 0,04 & 0,02 & 0,03 & 0,03 & 0,01 \\
\hline Burns, skin tears or cuts prevalence (bur0x) & 0,05 & 0,03 & 0,02 & 0,12 & 0,06 & 0,04 & 0,06 & 0,11 \\
\hline Little/no activity prevalence (soc02) & 0,57 & 0,32 & 0,68 & 0,41 & 0,56 & 0,46 & 0,43 & 0,50 \\
\hline Antipsychotic prevalence (drg01 ) & 0,30 & 0,21 & 0,38 & 0,36 & 0,22 & 0,34 & 0,13 & 0,45 \\
\hline High risk antipsychotic prevalence (drg02 ) & 0,78 & 0,41 & 0,67 & 0,64 & 0,46 & 0,71 & 0,42 & 0,72 \\
\hline Low Risk Antipsychotic prevalence (drg03 ) & 0,21 & 0,15 & 0,21 & 0,27 & 0,17 & 0,22 & 0,07 & 0,32 \\
\hline Antidepressant prevalence (adp01) & 0,37 & 0,30 & 0,08 & 0,43 & 0,26 & 0,50 & 0,22 & 0,38 \\
\hline Influenza vaccination prevalence (vac01) & 0,31 & 0,08 & 0,07 & 0,35 & 0,09 & 0,05 & 0,11 & 0,19 \\
\hline Indwelling catheter prevalence (cat02) & 0,01 & 0,02 & 0,00 & 0,02 & 0,00 & 0,01 & 0,00 & 0,01 \\
\hline Physical restraints use prevalence (res01) & 0,04 & 0,13 & 0,14 & 0,06 & 0,32 & 0,21 & 0,09 & 0,01 \\
\hline Late-loss ADL decline (adl01) & 0,20 & 0,33 & 0,22 & 0,22 & 0,24 & 0,20 & 0,19 & 0,38 \\
\hline ADL improvement (adl03) & 0,41 & 0,26 & 0,23 & 0,16 & 0,24 & 0,19 & 0,14 & 0,38 \\
\hline ADL decline following an improvement (adl02) & 0,15 & 0,25 & 0,16 & 0,05 & 0,17 & 0,08 & 0,09 & 0,49 \\
\hline Locomotion worsening (mob01) & 0,26 & 0,32 & 0,19 & 0,24 & 0,24 & 0,23 & 0,16 & 0,29 \\
\hline Falls increase (fal01) & 0,07 & 0,11 & 0,13 & 0,12 & 0,04 & 0,04 & 0,11 & 0,07 \\
\hline Cognitive decline (cog01 ) & 0,25 & 0,35 & 0,19 & 0,36 & 0,37 & 0,25 & 0,30 & 0,43 \\
\hline Communication decline (com01) & 0,25 & 0,38 & 0,33 & 0,28 & 0,30 & 0,17 & 0,19 & 0,39 \\
\hline Delirium new or persistent (del01) & 0,21 & 0,28 & 0,26 & 0,40 & 0,32 & 0,27 & 0,36 & 0,43 \\
\hline Behaviour problem decline (beh04) & 0,14 & 0,32 & 0,20 & 0,24 & 0,20 & 0,15 & 0,28 & 0,38 \\
\hline Bowel continence decline (cnt02) & 0,15 & 0,24 & 0,23 & 0,13 & 0,19 & 0,18 & 0,12 & 0,34 \\
\hline Bladder continence decline (cnt03) & 0,26 & 0,39 & 0,35 & 0,16 & 0,18 & 0,20 & 0,21 & 0,29 \\
\hline Weight loss (wgt01) & 0,07 & 0,03 & 0,05 & 0,06 & 0,05 & 0,06 & 0,07 & 0,11 \\
\hline Pain worsening (pan01) & 0,15 & 0,19 & 0,56 & 0,13 & 0,03 & 0,07 & 0,10 & 0,19 \\
\hline Pressure ulcers worsening (pru04) & 0,05 & 0,03 & 0,08 & 0,04 & 0,04 & 0,03 & 0,06 & 0,04 \\
\hline New indwelling catheter (cat01) & 0,01 & 0,00 & 0,00 & 0,00 & 0,00 & 0,02 & 0,01 & 0,01 \\
\hline
\end{tabular}

\footnotetext{
* For each LTCFQI, the best care (lowest LTCFQI score) country is shown in italics and the worst care (highest LTCFQI score) country is shown in boldface.
} 
LTC facilities in 7 European countries plus Israel that participated in the Services and Health for Elderly in Long TERm Care (SHELTER) project [13].

Even if the calculations are appropriate, see discussion below, the results of the measurements cannot be considered representative for the eight countries. The recruitment in the SHELTER project was for cost reasons not aimed at representative samples for each country, only a limited number of facilities in each of the countries therefore have participated. The results of individual facilities in a country can be quite different, as shown, as an example, for the four facilities from Finland. Our intention with this paper is to show that professional quality of care can be calculated and compared between locations. To obtain valid comparisons between countries much larger samples of facilities per country need to be included. It is possible, however, that some of the outcomes per country will persist when samples are larger, as is predicted by the experts of LTCF that co-authored this paper.

For the moment, the differences between individual facilities, within and across countries, are probably much more real. If so, what does that imply for an individual facility? This study enables a benchmark on quality of care. Feedback of the results can be used effectively to improve the quality of care in a facility, as has been shown by Boorsma et al. [14] in a RCT study. To achieve this, demands considerable efforts: continued collection of good data, training, routine use of the assessment outcomes in care planning, continued interest by the management of the facilities. The work environment of a Long Term Care Facility is complex with its $24 \times 7$ hours of care, work shifts, various disciplines with their own manners, interaction with family and volunteers, complex and emotional care demands, budget restraints. Besides, the real effort to improve quality of care needs to be made on the level of the wards, each with its own more or less independent management, work relations, manners and specific groups of residents. Most LTCFQIs, however, cannot be reliably calculated for wards, because of limited nominator and denominator numbers. Additional analysis by management of the facility, therefore, is required to identify problems with quality of care on particular wards.

The validity of the measurements of the LTCFQIs depends first of all on the accuracy of the assessment. In our study the assessors were adequately trained at the start, so that we may assume that the baseline assessment was fine and comparable between facilities in all of the countries [13]. At the time of the second assessment, approximately 6 months later, and the third at twelve months, knowledge may have decreased or increased. Facilities where assessments were completed by nurses that worked in these facilities, may have employed new nurses that possibly have not received the same level of assessment training. Facilities where the assessments have been used in routine care planning, as intended, and where computer output was distributed timely and where the results have been thoroughly discussed, nurses and their care teams have become more experienced and better at recognizing issues that are assessed with the interRAI LTCF instrument. In other facilities, where nothing or less than was intended has been done with the results of the assessment, the opposite can be true. It is even possible that in the latter facilities the second and third assessment have largely been copied from printouts of the baseline assessment. We suspect that some of the incidence LTCFQIs outcomes may have suffered from this. Continued good quality of the assessments needs firm external and internal incentives, as has been shown in the US and Canada where interRAI instruments now have been used on a large scale for some decades [19].

The calculation of QIs presumes that the facilities and their resident population are to a large extent comparable, i.e. in level of care, kind of care, kind of residents, focus of care. This has not necessarily been so in the SHELTER study. The person's living arrangement at the time of referral varied. In France, 45 percent of the residents came from a rehabilitation hospital. In England and the Czech Republic, most of the residents came from an acute hospital. In Italy, Israel and Germany the majority came from home. The number of residents in various Resource Utilization Groups, and length of stay [not presented in this paper], show that in some facilities (e.g., in Israel) most residents received extensive rehab, or stayed comparatively short (e.g., Czech Republic). Some of this is remedied by the risk adjustment, but likely not all.

In the calculation of the aggregate LTCFQI measure each QI has the same weight and the 75-th and 90-th percentile thresholds are equally important for each QI. These assumptions are obviously flawed. For some quality of care issues a number of QIs are available and for others maybe none. It is known to the authors that efforts are being made by interRAI to develop a more balanced aggregate measure on a subset of the QIs, including adding new QIs to the existing set that look at decline and improvement on particular issues simultaneously. Furthermore, the 75-th and 90-th percentiles are often useful, although not equally meaningful for each QI [3], but this has not been verified for all of the QIs, presented in this paper.

A further remark on the calculation of the QIs concerns the frequency of the assessment and the Facility Admission Profile risk adjustment. In the original research for the development of the QIs [5,6], residents were assessed at least every 3 months. In SHELTER, follow-up assessments were scheduled at 6 and 12 months. This affects the results of the incidence QIs, but probably not a large extent. The FAP values, however, which are used for risk adjustment, 
could in this study only be calculated when a resident was assessed at entry to the facility at baseline. This was rarely so, since the facilities were selected that had long-stay residents, which by definition have few new entries in a short period of time. And even so, risk adjustment through FAP values is not perfect.

Quality of life as experienced by the resident is as important as the calculation of professional quality of care and should, when possible, be measured and analyzed additionally to evaluate services delivered and prepare for enhanced services.

\section{Conclusion}

To conclude, the LTCQIs are useful measures of professional quality of care in Long Term Care facilities. The indicators are based on the worldwide used interRAI LTCF instrument. When the conditions for measurement are met the indicators appropriately measure quality of care. We have shown how the facilities in the SHELTER study, and to a lesser extent the countries, can be compared with each other with the LTCFQIs.

\section{Appendix}

We calculated the LTCFQIs as follows. We wrote SPSS syntax coding for the indicators, listed in Table 1. We executed this SPSS syntax on the SHELTER data. This generated for each QI an individual value for each resident, SPSS logistic regression analysis output tables for each of the LTCFQIs and risk-adjusted predicted QI values for each SHELTER resident. We transferred per facility (/country) the $\mathrm{N}$ of valid QI scores for a QI, the mean value of that QI, and the mean predicted value of the QI score (as derived from the logistic regression analysis), when applicable, to a MS EXCEL application. There we calculated the QI scores per facility (/country). When a QI score needed to be adjusted, we used the formula:

$$
\begin{aligned}
& \text { Adjusted LTCFQI } \mathrm{x}_{\mathrm{x}, \mathrm{y}} \\
& =1 /\left(1+\exp \left(-\ln \left(\operatorname{LTCFQI}_{\mathrm{x}, \mathrm{y}} /\left(1-\operatorname{LTCFQI}_{\mathrm{x}, \mathrm{y}}\right)\right)\right.\right. \\
& -\ln \left(\operatorname{predicted}_{\mathrm{x}, \mathrm{y}} /\left(1-\text { predicted }_{\mathrm{x}, \mathrm{y}}\right)\right) \\
& +\ln (\text { mean LTCFQI score } /(1 \text { - mean LTCFQI score }))) \text {, }
\end{aligned}
$$

where $\mathrm{LTCFQI}_{x, y}$ is the score for LTCFQI $x$ for facility (/country) $y$, and predicted ${ }_{x, y}$ is the mean value of the predictions of the values of LTCFQI $x$ for all individual residents of the facility (/country) $y$ as calculated by the SPSS logistic regression analysis.

\section{Additional file}

Additional file 1: Table S1. Aggregate summary scores of LTCF quality indicators at the level of the 8 countries participating in SHELTER.

\section{Competing interests}

The authors declare that they have no competing interests.

\section{Authors' contributions}

DHMF: substantial contribution to conception and design; analysis and interpretation; main author. GIC: contribution to conception and design; acquisition of data. HGvdR: acquisition of data; analysis and interpretation. RB: contribution to conception and design; acquisition of data. HFS: contribution to conception, acquisition of data; revision of content. $\mathrm{JCH}$ : contribution to conception, acquisition of data; interpretation of results; revision of content. AC: acquisition of data; revision of content. JG: acquisition of data; revision of content. All authors read and approved the final version.

\section{Acknowledgements}

The SHELTER Project was funded by the EU 7th Framework Programme. The authors wish to express their gratitude to LTC facilities that took part in the study, interRAI and the full SHELTER research team.

\section{Author details}

${ }^{1}$ EMGO Institute for Health and Care Research, VU University Medical Center, Amsterdam, the Netherlands. ${ }^{2}$ Centre for Health Service Studies, University of Kent, England, UK. ${ }^{3}$ National Institute for Health and Welfare, Helsinki, Finland. ${ }^{4}$ Research Unit, Health Environment and Ageing, Sainte Pèrine Hospital APHP and Versailles Saint Quentin University, Paris, France. ${ }^{5}$ Center for Standard in Health and Disability, Research Authority, Haifa University, Mount Carmel Haifa, Israel. ${ }^{6}$ Centro Medicina dell'Invecchiamento, Università Cattolica del Sacro Cuore, Rome, Italy.

Received: 13 September 2012 Accepted: 9 April 2013 Published: 15 April 2013

\section{References}

1. Hirdes JP, Zimmerman D, Haldaman KG, Soucie PS: Use of MDS quality indicators to assess quality of care in institutional settings. Canadian Journal of Quality in Health Care 1998, 14(2):5-17.

2. Morris JN, Hawes C, Fries BE, Phillips CD, Mor V, Katz S: Designing the national Resident Assessment Instrument for nursing homes. Gerontologist 1990, 30:293-307.

3. Zimmerman DR, Karon SL, Arling G, Clark BR, Collins T, Ross R: Development and testing of nursing home quality indicators. Health Care Financ Rev 1995, 16:104-127.

4. Rantz MJ, Petroski GF, Madsen RW, Scott J, Mehr DR, Popejoy L, et al: Setting thresholds for MDS (Minimum Data Set) quality indicators for nursing home quality improvement reports. Jt Comm J Qual Improv 1997, 23:592.

5. Mor V, Angelelli J, Jones R, Roy J, Moore T, Morris J: Inter-rater reliability of nursing home quality indicators in the U.S. BMC Health Serv Res 2003, 3:1-13.

6. Mor V, Berg K, Angelelli J, Teno JM, Miller SC: The quality of quality measurement in U.S. nursing homes. Gerontologist 2003, 43:37-46.

7. Moty C, Barberger-Gateau P, de Sarasqueta AM, Teare GF, Henrard JC: Risk adjustment of quality indicators in French long term care facilities for elderly people. A preliminary study. Rev Epidemiol Sante Publique 2003, 51:327-338.

8. Jones RN, Hirdes JP, Poss JW, Kelly M, Berg K, Fries BE, Morris JN: Adjustment of nursing home quality indicators. BMC Health Serv Res 2010, 10:96.

9. Carpenter GI, Gambassi G, Topinková E, Schroll M, Finne-Soveri UH, Henrard JC, Garms-Homolova V, Jonsson P, Frijters D, Ljunggren G, Sørbye LW, Wagner C, Onder G, Pedone C, Bernabei R: Community care in Europe. The aged in home care project (ADHOC). Ageing 2004, 16:259-269.

10. Bos JT, Frijters DHM, Wagner C, Carpenter Gl, Finne-Soveri, Topinková E, Garms-Homolova V, Henrard JC, Jonsson P, Sørbye LW, Ljunggren G, Schroll M, Gambassi G, Bernabei R: Variations in quality of Home Care between sites across Europe, measured with Home Care Quality Indicators. Aging Clin Exp Res 2007, 19:323-329.

11. Frijters DH, Carpenter Gl, Bos JT, Bernabei R: The calculation of quality indicators for Home Care agencies in 11 European countries. Tijdschr Gerontol Geriatr 2008, 39:44-54. 
12. Hirdes JP, Ljunggren G, Morris JN, Frijters DH, Finne Soveri H, Gray L, Björkgren M, Gilgen R: Reliability of the interRAl suite of assessment instruments: a 12-country study of an integrated health information system. BMC Health Serv Res 2008, 8:277.

13. Onder G, Carpenter Gl, Finne-Soveri H, Gindin J, Frijters D, Henrard JC, Nikolaus T, Topinkova E, Tosato M, Liperoti R, Landi F, Bernabei $R$, and the SHELTER project: Assessment of nursing home residents in Europe: the Services and Health for Elderly in Long TERm care (SHELTER) study. BMC Health Serv Res 2012, 12:5.

14. Boorsma M, Frijters DHM, Knol DL, Ribbe ME, Nijpels G, Hout HPJ: Effects of multidisciplinary integrated care on quality of care in residential care facilities for elderly people: a cluster randomized trial. CMAJ 2011. doi:10.1503/cmaj.101498.

15. Hirdes JP, Fries BE, Morris JN, Ikegami N, Zimmerman D, Dalby DM, Aliaga P, Hammer S, Jones R: Home Care Quality Indicators (HCQIs) based on the MDS-HC. Gerontologist 2004, 44:665-679.

16. Morris JN, Fries BE, Morris SA: Scaling ADLs within the MDS. Journal of Gerontology: Medical Sciences 1999, 54A:M546-M553.

17. Morris JN, Fries BE, Mehr DR, Hawes C, Phillips CD, Mor V: MDS cognitive performance scale. Journal of Gerontology: Medical Science 1994, 49:M174-M182.

18. Burrows AB, Morris JN, Simon SE, Hirdes JP, Phillips C: Development of an MDS-based depression rating scale for use in nursing homes. Age Ageing 2000, 29:165-172.

19. Hutchinson AM, Milke DL, Masey S, Johnson C, Squires JE, Teare G, Estabrooks C: Resident assessment instrument-minimum data Set 2.0 Quality indicators: a systematic review. BMC Health Serv Res 2010, 10:166.

doi:10.1186/1472-6963-13-138

Cite this article as: Frijters et al:: The calculation of quality indicators for long term care facilities in 8 countries (SHELTER project). BMC Health Services Research 2013 13:138.

\section{Submit your next manuscript to BioMed Central and take full advantage of:}

- Convenient online submission

- Thorough peer review

- No space constraints or color figure charges

- Immediate publication on acceptance

- Inclusion in PubMed, CAS, Scopus and Google Scholar

- Research which is freely available for redistribution 